\title{
Evaluation of the Impact of Educational Program on Elderly Knowledge about Osteoporosis
}

\author{
Nahed M. Saied Ayoub*; Sahar M. Soliman **
}

\begin{abstract}
Osteoporosis is a major public health affects or threatens an estimated 150 million women and men worldwide. Approximately 7\% of all women aged 35-40 years and 33\% of women older than 65 years have involutional osteoporosis. The World Health Organization define osteoporosis as "a skeletal disorder characterized by compromised bone strength predisposing to an increased risk of fracture." The aim of this study was to assess the elderly knowledge about osteoporosis and to evaluate the impact of educational program on elderly knowledge about osteoporosis. The study was carried out in El-Saada elderly club at Talkha, Mansura district. The study subject comprised 31 elderly visiting El-Saada elderly club regularly. A quasi experimental study was used in the study through evaluating the elderly knowledge about osteoporosis prior to the development of the educational program by using structured interview questionnaire sheet, after implementation of the program the same questionnaire was used to reassess the elderly knowledge immediately after program implementation and after one month of implementation. The results revealed a lack of knowledge which improved in the immediate post test but the knowledge declined after one month in some items. The study recommended that regular educational program should be held to increase their awareness, which helps them to catch the sign of the disease and prevent it. Key words: osteoporosis, elderly knowledge and educational program.
\end{abstract}

\section{INTRODUCTION:}

Osteoporosis is a systematic skeletal disorder, characterized by reduced bone mass, deterioration of bone structure, increase bone fragility and increased fracture risk ${ }^{(1,2)}$ This disease is a major threat to public health today and the most common bone disease world wide. By 2015, The National
Osteoporosis Foundation predicts that 41 million people aged 50 years or older will have the disease unless something is done to improve diagnosis and treatment.(2) Osteoporosis affects more than 75 million people in Europe. ${ }^{(3)}$ The prevalence rate of osteoporoses in Egypt was 5.237.182 persons in $2004^{4}$

\footnotetext{
* Gerontological Nursing Department, Faculty of Nursing, Mansoura University

** Community Nursing Department, Faculty of Nursing, Mansoura University
} 
The risk of developing osteoporosis among women doubles every 5 years, one in three women and one in eight men over the age of fifty are thought to be affected with the disease. After age 50 , one in every two women and one in every four men will sustain some type of osteoporosis-related fracture $(5,6)$.

Various risk factors are known to increase the rate of bone loss. These can be divided into three groups: Nonmodfiable risk factors, modifiable risk factors and factors or causes related to other medical conditions or drug therapy. Non-modfiable causes of increased bone loss are increasing age, race, both sex are affected, family history, and significantly decrease of estrogen level after menopause around $25 \%$ and $75 \%$, respectively. The bone mass in both sexes remains stable until age 45-55 years, The accelerated bone loss in women causes the loss of $25-30 \%$ of skeletal mass over 5-10 years, followed by a slower phase with stable loss rates of $0.5-1 \%$ per year. Males did not have an accelerated bone loss, but rather, a stable loss rate ${ }^{(7,8)}$

While modifiable causes are inactivity (sedentary lifestyle), tobacco, use of colas, caffeine, reduced calcium intake, decreased production of active vitamin $D$, higher salt intake, and heavy alcohol intake. Medications associated with osteoporosis are glucocorticoids, drugs that induce hypogonadism, anticonvulsants, and excessively high levels of thyroid hormone. Also some diseases can increase the risk of osteoporosis: Crohn's disease, liver disease, rheumatoid arthritis, inflammatory bowel disease, lymphomas, multiple myeloma, thalassemia, acromegaly, amyloidosis, early 
menopause, the removal of the ovaries, and leukemia.(8,9)

There are 2 types of osteoporosis type I (postmenopausal osteoporosis) generally develops after menopause, when estrogen levels drop precipitously, leading to bone loss - usually in the trabecular (spongy) bone inside the hard cortical bone. Type I osteoporosis is characterized by increased bone resorption due to osteoclastic activity and is generally related to estrogen deficiency. Vertebral crush fractures and fractures of the distal radius (Colles fractures) are the main complications $^{(10,11)}$. Type II osteoporosis (senile osteoporosis) occurs when there is excessive bone loss manifested after age 70 years in both women and men. Type II osteoporosis results from normal aging and is associated with a steady, 1$2 \%$ loss of cortical and trabecular bone mass each year. Age-related bone loss begins at age 35-40 years when the balance shifts to favor resorption and the skeleton begins to lose bone mass. Hip and vertebral fractures are most common in this type of osteoporosis. ${ }^{(12)}$

Osteoporosis is sometimes called the "silent disease", proceeded by minimal to almost zero symptoms. If the disease is not treated or prevented it may be painless until fracture occurs. ${ }^{(13)}$ Most fractures created from osteoporosis take place in hip, spine, wrist, and ribs, yet the disease may affect any bone in the body which may lead to spinal deformity, height loss, chronic or sever pain, dependency, decreased lung capacity, difficulty of sleeping. ${ }^{(13,14)}$ The National Osteoporosis Foundation states that osteoporosis can be prevented and can be effectively being treated before significant bone loss has occurred. 
Osteoporosis can be significantly awareness and to help in early decreased by preventive measures such detection. ${ }^{(23)}$ as stop smoking, avoid salt, avoid colas, and exercise daily ${ }^{(15,16)}$. Take an adequate dose of vitamin C $(500$ mglday), vitamin D (800-1200 IU/day), calcium 1000-1500 mg/day calcium-toprotein ratio is $20: 1$ ( $\mathrm{mg}$ calcium $/ \mathrm{g}$ protein), magnesium (250 mg once or twice a day), vitamin $\mathrm{K}$ (500-1000 $\mathrm{mcg} /$ day), vitamin B-12, B6, folic acid, and avoid excessive animal meat. Although osteoporosis is often thought as an older person's disease, it can strike at any age. ${ }^{(17-22)}$

Therefore, nurses are in a position to play a pivotal role in supporting elderly and advising them about treatment and prevention of osteoporosis, as well as to make a significant contribution to research in this area and establish educational program to increase elderly

\section{Aim of the study:}

- To assess the elderly knowledge about osteoporosis.

- To increase elderly awareness about osteoporosis

- To evaluate the impact of educational program on the elderly knowledge about osteoporosis and its prevention.

DESIGN: A quasi experimental design was used in the study.

\section{Setting:}

The study was carried out in ElSaada elderly club at Talkha, in Mansura district on Tuesday for availability of large number of elderly in that day. The study lasted 6 months starting from January 2006 to June 2006. 


\section{Subjects:}

The subject comprises 46 elderly out of 100 elderly who were attending ElSaada elderly club. 15 of them was excluded because 9 did not complete the program and 6 didn't came after one month for reassessment Just 31 elderly who are willing to complete the study,.

Tools of the study:

Two tools were developed to collect required data. Tool one consists of knowledge test and the second tool is the educational program.

I-Interview questionnaire:

Interview questionnaire was developed, based on the review of relevant literatures, to assess the elderly knowledge about osteoporosis. It comprises two parts:

1. Part One includes the which included all topics about sociodemographic data of the elderly osteoporosis. such as age, sex, and level of education.

2. Part Two includes the essential knowledge assessment tool to assess the elderly about the diseases as regards definition, risk factors, signs and symptoms, sites, and prevention. The analysis was performed by scoring 1 for the correct response and 0 for an incorrect or don't know response. The total score of the test was 48 covering six topics namely; the nature of the disease, 31 scores (definitions of osteoporosis, occurrence, the risk factors, sites, and signs and symptoms) and 17 scores for prevention.

\section{II-Educational program}

Implement the educational program 
Methods:

\section{1-Administrative process:}

A-Official approval was obtained from the manager of the elderly club to conduct this study.

\section{2-Development of the study tools:}

a- The Structured interview questionnaire sheet was developed by researchers to assess the basic knowledge of the subject.

b- A jury was appointed to test content validity and clarity by 5 expertises in gerontology and nursing community field. The necessary modifications were done.

c- A pilot study was carried out on five elderly chosen randomly from ElSaada elderly club but excluded from the subject and are not included in the study to test feasibility of the tool. d- Each elderly included in the study was informed about the aim of the study.

e- Oral consent was taken from the elderly engaged in the study.

\section{3-Program development:}

a- The result of pretest was used to assess the target group. The educational program covers all topics of osteoporosis, Namely: osteoporosis definition, risk factors, signs and symptoms, most affected sites, methods of prevention, and health teaching about diet, exercise, and vitamin $\mathrm{D}$.

b- The program consists of 4 sessions divided on two days every session half hour. The program was repeated two times throughout two weeks for two groups of elderly one group included 15 elderly and the other group included 16 elderly. 
c- A variety of interactive teaching median minimum and maximum were techniques that encourage used rather than the mean. The interactive group discussions, Wilcoxon Signed Ranks test was used interactive lecture, and for paired comparison of knowledge brainstorming. Trainers used power score before and after intervention. The point presentation, flip chart, and Mann-Whitney test was used for distributed handouts comparison of the median change in

d- Reassess the elderly knowledge by percentage knowledge score between using the same interview the study groups. All reported $p$ values questionnaire, immediately after are two-tailed. The level of significance implementation of the program and was set at $0.05^{(24)}$ after one month from the end of the

\section{RESULT} program

Table (1) revealed the distribution of

\section{Statistical Analysis}

Data were analyzed using SPSS software version 13.0. The KolmogorovSmirnov test was used to examine the normality of the shape of knowledge score distribution. As the distribution was not normal, so non-parametric measures were used. The median together with the studied elderly to their personal characteristics. As regards to age, the majority of the studied group was female $(87.1 \%)$ and the minority was male (12.9\%.) Regarding to age, $83.9 \%$ of them were categorized as young-old group and $16.1 \%$ categorized as Middleold group while no one was categorized as old-old group. as Regards marital 
status, the majority of the studied sample was widowed( $61.3 \%$ ) and the minority was not married (3.2\%).Concerning their educational level, almost half of the sample had university degree while only $3.2 \%$ was illiterate and nearly threequarters $(74.2 \%)$ were housewives.

Table (2) shows the different knowledge scores in studied elderly related to osteoporosis topics before and after assessment, the knowledge scores regarding to base line definition, method, signs, symptoms, and sites ranged from $0-100 \%$ while the knowledge related to risk factors ranged from 55.6-88.9\% while prevention ranged from 33.3-100\% The knowledge at the first followup was increased to $100 \%$ regarding to definition, signs and symptoms, sites and prevention while risk factors ranged from $61.1-100 \%$ but the method ranged from 33.3-100\%.
Concerning second follow up, the knowledge declined but still significant in several items namely: definition, method of prevention, and risk factors.

Figure (1) represents knowledge of elderly before and after the educational program. This figure revealed that there was lack of knowledge related to the majority of topics namely: pathphysiology, risk factors, manifestations, location, and prevention except in definition they were aware of it before the program. While there was gain of knowledge of all topics after educational program in the first assessment. But a decline in knowledge was noticed related to risk factors in the second assessment

Table (3) demonstrates the relation between elderly knowledge score and personal characteristics. None of the factors showed significant effect on 
knowledge score except education. The faculty level showed significantly higher median score $(72.45 \%)$ in comparison to the secondary level or lower educational level $(53.06 \%)$. On the other hand, the change in knowledge level whether at first follow-up visit or at one month did not show any statistical significant difference by sociodemographic factors.

\section{DISCUSSION}

Osteoporosis is a disease reaching epidemic proportions in the elderly population especially among postmenopausal women. Women of all ethnic and racial origins are affected, as men and younger women. ${ }^{(2,5)}$ The risk of osteoporosis increases after the age of 65 and fracture risk doubles for each additional 5-10 years of age. hand, the study in Salvador 2004(27) International Osteoporosis Foundation World Congress $2002^{(5)}$ revealed that the fight against osteoporosis is a fight to liberate millions of people, over 200 million people worldwide suffer from this disease, and the majority of them were women that profoundly restrict life's opportunities $^{(5,25)}$. Healy 2000(26) illustrated that the first priority lies in prevention of osteoporosis.

The present study revealed lack of knowledge among elderly related to osteoporosis topics including types of osteoporosis, signs and symptoms, sites affected and preventive measures which is agreed with other studies in ElSalvador 2004(27), African-American women $^{(28)}$, USA, North Europe ${ }^{(29)}$, and Canadian which illustrated that the elderly women have poor knowledge about the osteoporosis. ${ }^{(30)}$ On the other showed that women with secondary or higher education obtained significantly higher total knowledge scores. This was 
in agreement with the present study this may be due to that the expectancy at which showed that higher educational birth in Egypt is 70.1 years at 2004(32).

level showed significant higher median Osteoporosis and associated fracture score. became a chronic burden on individual

As regards to risk factors associated and society, therefore, it is important to with osteoporosis the present study increase community and elderly revealed that more than fifty percent of awareness about osteoporosis and the elderly have knowledge about risk prevention which can be done through factors, which was different from other educational program. There lore study carried out in Mexico(31), which educational program have been found that the women had lack of identified as a crucial strategy in the knowledge about risk factors, the main prevention ${ }^{(23)}$.

focus was menopause is the only cause This study demonstrates that associated with osteoporosis. While educational program increases elderly other studies in USA \& North Europe knowledge and awareness about revealed that most of the studied women osteoporosis and its prevention which were not aware about risk factors of agree with the previous studies. Also osteoporosis. $^{(29)}$

they indicted that educational program

It was observed in the present study provides a basis of knowledge about that the elderly people located in two osteoporosis. In addition, two studies categories young-old 60-74 and middle- were done in Hong Kong 2006(33,34), old 75-84 but no one was old-old (85+) revealed positive effect of osteoporosis 
educational program on women and men knowledge. This is in agreement with the present study which illustrated that the elderly knowledge and awareness increased after educational program regarding osteoporosis items, but the knowledge declined in second assessment regarding to risk factors only which indicates that although their ability to retained knowledge decreased with age they still aware that disease threatens the public and threatens the elderly so it is as important to take preventive action toward osteoporosis.

\section{CONCLUSION}

The study concluded that the elderly people had lack of knowledge related to osteoporosis, while a positive effect was noticed after the educational program there was declined in knowledge related to risk factors at second assessment. As regard sociodemographic factors. None of the factors showed significant effect on knowledge score except education, the faculty level showed significantly higher. Also the change in knowledge level whether at first follow-up visit or at one month did not show any significant difference by sociodemographic factors.

\section{REOMMENDATIONS}

1-Education messages targeted to postmenopausal women that identify risk factors, promote regular exercise and physical activity, intervention, and treatment strategies are recommended 2-Its suggested to provide each elderly with booklet containing types of osteoporosis, sites, signs, symptoms, risk factors, and prevention.

3- The study is recommended that osteoporosis education campaigns should be directed at families as well as individuals, to educate children about the importance of calcium in the diet, whether as dairy products or in other calcium-rich 
products such as Soya milk, vegetables,

and fruits

Table 1: Distribution of the studied elderly according to their personal characteristics

\begin{tabular}{|c|c|c|}
\hline Personal characteristics & $\begin{array}{l}\text { Frequency } \\
\mathrm{N}=31\end{array}$ & $\%$ \\
\hline \multicolumn{3}{|l|}{ Gender } \\
\hline Female & 27 & 87.1 \\
\hline Male & 4 & 12.9 \\
\hline \multicolumn{3}{|l|}{ Age } \\
\hline Young-old 60-74 & 26 & 83.9 \\
\hline Middle-old 75-84 & 5 & 16.1 \\
\hline Total & 31 & 100 \\
\hline \multicolumn{3}{|l|}{ marital status } \\
\hline widow & 19 & 61.3 \\
\hline married & 11 & 35.5 \\
\hline not married & 1 & 3.2 \\
\hline \multicolumn{3}{|l|}{ Education } \\
\hline illiterate & 1 & 3.2 \\
\hline primary school & 4 & 12.9 \\
\hline preparatory school & 1 & 3.2 \\
\hline secondary or middle & 9 & 29.0 \\
\hline faculty education & 16 & 51.6 \\
\hline \multicolumn{3}{|l|}{$\begin{array}{ll}\text { Occupation } & \text { before } \\
\text { retirement } & \end{array}$} \\
\hline housewife & 23 & 74.2 \\
\hline employee & 8 & 25.8 \\
\hline
\end{tabular}

N.B There was not any one have $85 y$ years old or more old-old-85 
Table 2: The difference of knowledge scores in studied elderly related to osteoporosis topics before and after educational program

\begin{tabular}{|c|c|c|c|c|c|c|}
\hline \multirow[t]{2}{*}{ Subscales } & Baseline & First follow-up & $\begin{array}{l}\text { Second } \\
\text { follow-up }\end{array}$ & \multicolumn{3}{|c|}{$\begin{array}{l}\text { Wilcoxon Signed Ranks } \\
\text { Test }\end{array}$} \\
\hline & $\begin{array}{c}\text { Median } \\
\text { (Min - Max) }\end{array}$ & $\begin{array}{c}\text { Median } \\
(\text { Min - Max) }\end{array}$ & $\begin{array}{c}\text { Median } \\
(\text { Min - Max) }\end{array}$ & $\begin{array}{c}1 V s \\
2\end{array}$ & $\begin{array}{c}1 V s \\
3\end{array}$ & $2 V s 3$ \\
\hline Definition & $\begin{array}{c}100 \\
0-100\end{array}$ & $\begin{array}{c}100 \\
100-100\end{array}$ & $\begin{array}{c}100 \\
66.67-100\end{array}$ & $3.13^{*}$ & 1.06 & $3.00^{*}$ \\
\hline Types & $\begin{array}{c}33.33 \\
0-100\end{array}$ & $\begin{array}{c}66.67 \\
33.33-100\end{array}$ & $\begin{array}{c}\mathbf{6 6 . 6 7} \\
33.33-100\end{array}$ & $2.91^{*}$ & $4.21^{*}$ & $2.36^{*}$ \\
\hline $\begin{array}{l}\text { Risk } \\
\text { factors }\end{array}$ & $\begin{array}{c}\mathbf{5 5 . 5 6} \\
55.6-88.89 \\
\end{array}$ & $\begin{array}{c}100 \\
61.11-100\end{array}$ & $\begin{array}{c}\mathbf{6 1 . 1 1} \\
55.6-100\end{array}$ & $3.21^{*}$ & 1.94 & 1.33 \\
\hline $\begin{array}{l}\text { Sign\& } \\
\text { symptoms }\end{array}$ & $\begin{array}{c}5.00 \\
0-100\end{array}$ & $\begin{array}{c}100 \\
100-100\end{array}$ & $\begin{array}{c}100 \\
0-100\end{array}$ & $3.85^{\star}$ & 1.73 & $2.40^{*}$ \\
\hline Sites & $\begin{array}{c}66.67 \\
0-100\end{array}$ & $\begin{array}{c}100 \\
100-100\end{array}$ & $\begin{array}{c}100 \\
0-100\end{array}$ & $3.57^{\star}$ & 1.60 & $2.25^{*}$ \\
\hline Prevention & $\begin{array}{c}\mathbf{9 4 . 4 4} \\
33.33-100 \\
\end{array}$ & $\begin{array}{c}100 \\
100-100\end{array}$ & $\begin{array}{c}100 \\
33.33-100\end{array}$ & $3.23^{*}$ & 1.30 & $2.38^{*}$ \\
\hline Total & $\begin{array}{c}69.39 \\
28.57-93.88 \\
\end{array}$ & $\begin{array}{c}97.96 \\
81.63-100\end{array}$ & $\begin{array}{c}\mathbf{8 5 . 7 1} \\
30.61-100\end{array}$ & $4.30^{*}$ & $2.28^{*}$ & 1.67 \\
\hline
\end{tabular}

- $\quad \mathrm{P}<0.05$ (Significant)

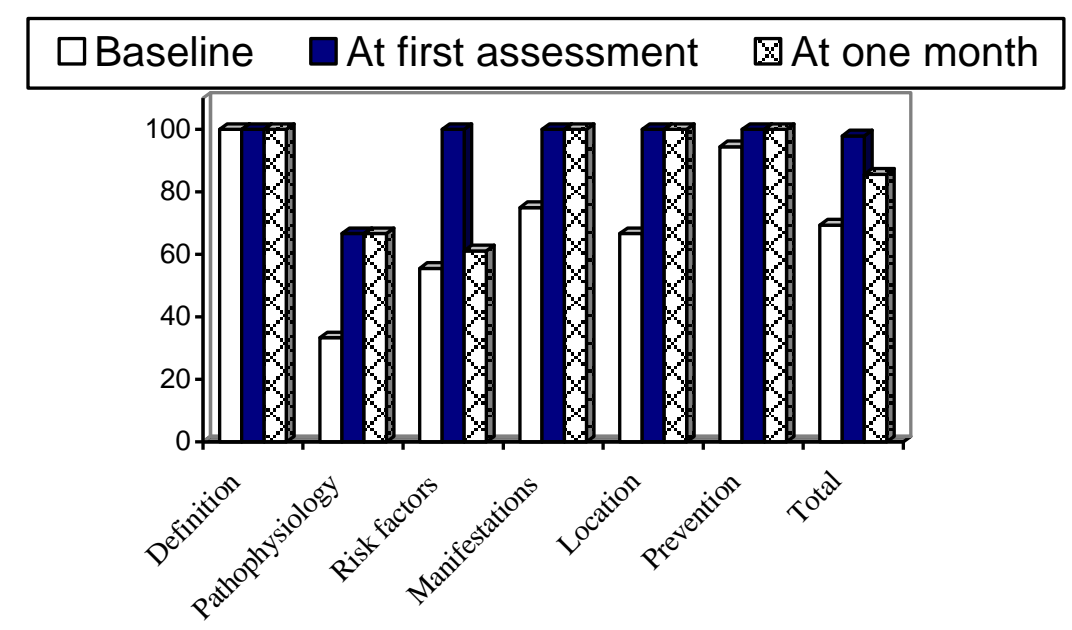

Figure 1 knowledge of elderly before and after the educational progra 
Table 3: The relation between elderly knowledge score before and after program and there characteristics

\begin{tabular}{|c|c|c|c|c|c|}
\hline \multirow{2}{*}{\multicolumn{2}{|c|}{ Characteristics }} & \multirow[t]{2}{*}{$n$} & \multirow{2}{*}{$\begin{array}{l}\text { Base line } \\
\text { Median(Min/ Max) }\end{array}$} & \multirow{2}{*}{$\begin{array}{l}\text { First follow-up - } \\
\text { Baseline } \\
\text { Median(Min/ } \\
\text { Max) }\end{array}$} & \multirow{2}{*}{$\begin{array}{l}\text { Second } \\
\text { follow-up } \\
\text { First follow-up } \\
\text { Median(Min/ } \\
\text { Max) }\end{array}$} \\
\hline & & & & & \\
\hline Total & & 31 & $\begin{array}{l}\text { 69.39(28.57 } \\
93.88)\end{array}$ & $\begin{array}{l}22.45(- \\
8.16 / 71.43)\end{array}$ & $\begin{array}{l}-4.08(- \\
55.10 / 18.37)\end{array}$ \\
\hline Age & $\begin{array}{l}\text { Young old } \\
\text { Middle-old }\end{array}$ & $\begin{array}{l}26 \\
5\end{array}$ & $\begin{array}{l}69.39(28.57 / 89.80) \\
75.51(44.90 / 93.88)\end{array}$ & $\begin{array}{l}25.51(- \\
8.16 / 71.43) \\
12.25(6.12 / 55.10)\end{array}$ & $\begin{array}{l}-4.08(- \\
55.10 / 18.37) \\
0(- \\
14.29 / 18.37)\end{array}$ \\
\hline Mann-Whit & ey test & & 0.59 & 0.46 & 1.19 \\
\hline Sex & $\begin{array}{l}\text { Male } \\
\text { Female }\end{array}$ & $\begin{array}{l}4 \\
27\end{array}$ & $\begin{array}{l}67.35(44.90 / 93.88) \\
69.39(28.57 / 89.80)\end{array}$ & $\begin{array}{l}23.47(6.12 / 55.10) \\
22.45(- \\
8.16 / 71.43)\end{array}$ & $\begin{array}{l}-9.18(- \\
14.29 / 0) \\
-4.0816(- \\
55.10 / 18.37)\end{array}$ \\
\hline Mann-Whit & ey test & & 0.50 & 0.00 & 0.33 \\
\hline Education & $\begin{array}{l}\text { Below } \\
\text { secondary } \\
\text { secondary } \\
\text { or higher }\end{array}$ & $\begin{array}{l}6 \\
25\end{array}$ & $\begin{array}{l}61.22(44.90 / 81.63) \\
71.43(28.57 / 93.88)\end{array}$ & $\begin{array}{l}29.59(0 / 55.10) \\
20.41(- \\
8.16 / 71.43)\end{array}$ & $\begin{array}{l}1.02(- \\
55.10 / 18.37) \\
-4.08(- \\
51.02 / 18.37)\end{array}$ \\
\hline Mann-Whit & ey test & & 0.40 & 0.23 & 1.49 \\
\hline $\begin{array}{l}\text { Marital } \\
\text { status }\end{array}$ & $\begin{array}{l}\text { Married } \\
\text { Unmarried }\end{array}$ & $\begin{array}{l}11 \\
20\end{array}$ & $\begin{array}{l}67.35(38.78 / 93.88) \\
70.41(28.57 / 89.80)\end{array}$ & $\begin{array}{l}32.65(- \\
8.16 / 61.22) \\
21.43(0 / 71.43)\end{array}$ & $\begin{array}{l}-4.08(- \\
51.02 / 6.12) \\
-4.08(- \\
55.10 / 18.37)\end{array}$ \\
\hline Mann-Whit & ey test & & 0.06 & 0.12 & 0.71 \\
\hline $\begin{array}{l}\text { Occupation } \\
\text { before } \\
\text { retirement }\end{array}$ & $\begin{array}{l}\text { Housewife } \\
\text { Employee }\end{array}$ & $\begin{array}{l}23 \\
8\end{array}$ & $\begin{array}{l}67.35(28.57 / 89.80) \\
81.63(44.90 / 93.88)\end{array}$ & $\begin{array}{l}28.57(- \\
8.16 / 71.43) \\
16.33(0 / 55.10)\end{array}$ & $\begin{array}{l}-4.08(- \\
55.10 / 18.37) \\
-9.18(- \\
16.33 / 2.04) \\
\end{array}$ \\
\hline Mann-Whit & ey test & & 1.76 & 0.93 & 0.48 \\
\hline
\end{tabular}

\section{REFERENCES}

1- WHO Study Group. Assessment of fracture risk and its application to screening for postmenopausal osteoporosis. WHO Technical Report Series, no. 843. Geneva,
Switzerland: World Health Organization; 1994. 1-129.

2- Clung B, Cathy RK. Foundation of osteoporosis research andeducation, Continuing: Evaluation and management and fracture risk in 
postmenopausal women. Guidelines for Patient Evaluation 2007.

3- Diaz M, Carrasco J. On the behalf of the Multicenter Research Project on osteoporosis, study on bone mineral density (BMD) in lumber spine and femoral neck. Osteoporosis Int.1997,7:59-64

4- El-Shazly S, Mohamed N. Measuring thequality of life among elderly with osteoporosis. ASNJ. 2007;6(2):12-7.

5- Kessenich CR. Osteoporosis and other skeletal disease. In: International Osteoporosis Foundation and other skeletal Fighting Conference. Osteoporosis Action. 2002;6(2).

6- Hannan MT, Tucker KL, DawsonHughes B. Effect of dietary protein on bone loss in elderly men and women: The Framingham Osteoporosis Study. J Bone Miner Res. 2000,15:2504-12.

7- Cooper C. Epidemiology of osteoporosis. In: Geenspan SN. Primer on the Metabolic Bone Diseases and Disorders of Mineral Metabolism. $5^{\text {th }}$ ed USA, Mosby: 2003.307-313.

8- Hess.E, Ebersole P, Patricia H. Geriatric and Nursing Health Aging. 3rd ed, Philadelphia, London, Sydney, Toronto: 2001. 407-412.

9- Fleming R, Patrick K. Osteoporosis prevention: pediatricians" knowledge, attitudes, and counseling practices. Prev

Med. Apr 2002;34(4):411-21.

10- Finkelstein JS, Hayes A, Hunzelman JL. The effects of parathyroid hormone, alendronate, or both in men with osteoporosis. $\mathrm{N}$ Engl J Med. 2003;349(13):1216-26
11- Roach S. Introductory Gerontological Nursing. $2^{\text {nd }}$ ed USA: Mosby Comp; 2003;355-359.

12- Hart DW, Herndon DN, Klein $G$, Attenuation of posttraumatic muscle catabolism and osteopenia by long-term growth hormone therapy. Ann

Surg. $2001 ; 233(6): 827-47$.

13- Eliopoulos C. Gerontological Nursing. $4^{\text {th }}$ ed. Philadelphia, Newyork: Lippincott; 1997. 323-326

14- Bunker VW. Management of osteoporosis: Scottish Intercollegaite Guidelines Ntework, June Tanna N. Hormone replacement therapy: risks and benefits. Pharmaceeutical Journal. 2003;271:646-8.

15- National Institutes of Health. Osteoporosis prevention, diagnosis, and therapy. $\mathrm{NIH}$ Consens Statement. 2000;17(1):145.

16- Lueckenotte.AG.Gerontologic

Nursing $\quad 2^{\text {nd }}$ ed. USA: Mosby; 2000.2741-744

17- Center for Nutrition Policy and Promotion. Family economics and nutrition review. Special issue elderly nutrition 15(1): 2003

18- Schwarz R Magnesium metabolism. In: Simmons DJ. Nutrition and Bone Development. New York: J Oxford University Press; 1990. 148-63.

19- Dawson-Hughes $B$ and Harris SS .Calcium intake influences the association of protein intake with rates of bone loss in elderly men and women. Am J Clin Nutr. 2002, 75:773-9.

20- Iwamoto J, Takeda T, Sato $Y$ Effects of vitamin $\mathrm{K} 2$ on 
osteoporosis. Curr Pharm Des. 2004,10:2557-76

21- Standing Committee on the Scientific Evaluation of Dietary Reference Intakes. 1997 Dietary reference intakes: calcium, phosphorus, magnesium, vitamin $\mathrm{D}$, and fluoride. Institute of Medicine, Washington, DC: National Academy Press; 1997.

22- Morselli B, Neuenschwander B, Perrelet R, Lippuner K Osteoporosis diet. Ther Umsch. 2000 Mar 57(3):152-60

23- WhiteheaDD, Keast J. Montgomery Vand Hayman S. Preventire health education program for osteoporosis. Journal of Advanced Nursing. 2004; 47(1), 15-24

24- Norman GR, Streiner DL. Biostatistics, the bare essentials. 2nd ed. Hamilton, BC Decker Inc; 2000.

25- Cooper C, Campion G, Melton LJ. Hip fractures in the elderly: a worldwide projection. Osteoporos Int. 1992;2(6):285-9.

26- Healy P. Homik J, Suarz-Almazer M.E, Shea B, Cransy H, Wells G, et al. Bone of contention. calcium \& vit For corticosteroid. Nursing Standard. 2000;14(48)11.

27- Roberto HR, Sandra MG. Osteoporosis-related life habits and knowledge about osteoporosis among women in El Salvador: A cross-sectional study. BMC Musculoskeletal Disorders. 2004, 5:29doi:10.1186/1471-2474-5-29.
28- Von Hurst PR Wham CA. Attitudes and knowledge about osteoporosis risk prevention: a survey of New Zealand women. Public Health Nutr. 2007 Jul;10(7):747-53

29- Winzenberg T, Oldenuburg B, Jones G. The design of a valid and reliable questionnaire to measure osteoporosis knowledge in women: The Osteoporosis Knowledge Assessment Tool. BMC Musculoskeletal Discords. 2003; 4(17):171-87.

30- Ribeiro V, Blakeley J, Laryea M. Women's knowledge and practices regarding the prevention and treatment of osteoporosis. National Library of Medicine. 2000; 21(4):34753.

31- NICHP Report, Ministry of Health and Population 2005. Egypt: Human Development Report; 2004.

32- Orces CH, Casas C, Lee S, Garci Cavazos R, White W: Determinations of osteoporosis prevention in low-income MexicanAmerican Women. South Med J. 2003;96:458-464

33- Chan MF, Ko CY. Osteoporosis educational program for women Black well Journal of Advanced Nursing. 2006;54(2):159-70.

34- Tung WC and Lee FK, Effect of an osteoporosis educational program for men Black well Journal of Advanced Nursing. 2006; 1365-2648 